THE CULTURAL REVOLUTION AT THE MARGINS 



\title{
THE \\ CULTURAL \\ REVOLUTION \\ AT THE MARGINS
}

CHINESE SOCIALISM IN CRISIS

YICHING WU

\author{
II \\ II \\ Harvard University Press \\ Cambridge, Massachusetts \\ London, England \\ 2OI 4
}


Copyright $@ 20 \mathrm{I} 4$ by the President and Fellows of Harvard College

All rights reserved

Printed in the United States of America

\section{Library of Congress Cataloging-in-Publication Data}

Wu, Yiching.

The cultural revolution at the margins : Chinese socialism in crisis / Yiching Wu.

$$
\text { p. cm. }
$$

Includes bibliographical references and index.

ISBN 978-0-674-72879-o (alk. paper)

г. China-History-Cultural Revolution, I966-I976. 2. Hong wei bing.

3. Protest movements-China-Beijing-History-2oth century.

4. Student movements-China-Beijing-History—2oth century.

5. Political violence-China-Beijing-History—2oth century.

6. Socialism-China-History-2oth century. I. Title.

DS778.7.W 852014

$$
951.05^{1} 6 \text {-dc23 2013042654 }
$$


This book is dedicated to my parents, Wu Feng and Xu Guoguang 

A total description draws all phenomena around a single centrea principle, a meaning, a spirit, a world-view, and overall shape; a general history, on the contrary, would deploy the space of dispersion.

-Michel foucault, The Archaeology of Knowledge

The history of subaltern groups is necessarily fragmented and episodic. There undoubtedly does exist a tendency to (at least provisional stages of) unification in the historical activity of these groups, but this tendency is continually interrupted by the activity of the ruling groups; it therefore can only be demonstrated when a historical cycle is completed and this cycle culminates in a success. Subaltern groups are always subject to the activity of ruling groups, even when they rebel and rise up: only "permanent" victory breaks their subordination, and that not even immediately. 
